\title{
Entre modulações musicais e literárias: O inverno e depois, de Luiz Antonio de Assis Brasil
}

\author{
Between literary and musical modulations: \\ O inverno e depois, by Luiz Antonio de Assis Brasil
}

\author{
MARIA ZILDA FERREIRA CURY ${ }^{1}$ \\ Guilherme Augusto LOPES DE SOUZA ${ }^{1}$
}

${ }^{1}$ Universidade Federal de Minas Gerais (UFMG). Belo Horizonte, MG, Brasil.

Resumo: O inverno e depois, romance de Luiz Antonio de Assis Brasil, exibe uma articulada reflexão acerca da música clássica e da vida de artista, assim como os desafios dos musicistas de traduzir, por meio de sua arte, os sentimentos que as palavras não expressam. À vista disso, pretende-se fazer uma leitura do romance a partir das teorias dos estudos músico-literários, evidenciando as influências do Concerto para violoncelo e orquestra, de Antonín Dvořák - peça chave do romance - na narrativa de Assis Brasil, tanto no plano estrutural, como no plano de seu conteúdo.

Palavras-chave: Literatura brasileira contemporânea; Luiz Antonio de Assis Brasil; Literatura e música; Intermidialidade; Estudos músico-literários.

\begin{abstract}
O$ inverno e depois, a novel written by Luiz Antonio de Assis Brasil, exposes an articulated reflection on classical music and the artist's life, as well as the challenges of the musicians to translate, through their art, the feelings that words do not express itself. In this way, we intend to make a reading of the novel from the theoretical aspects of word and music studies, revealing the influences of the Concerto for violoncello and Orchestra, by Antonín Dvořák - key factor for the novel -, in the Assis Brasil's narrative, both in the structural plane and in the plane of its content.
\end{abstract}

Keywords: Contemporary brazilian literature; Luiz Antonio de Assis Brasil; Literature and music; Intermidiality; Musico-literary studies.

"A música da língua deve expressar o que a lógica da língua obriga a crer." 
Literatura e música dialogam desde sempre: no nascimento da tragédia e do gênero dramático, por exemplo, poesia e música se encontravam, unindo-se nos hinos que eram entoados em honra aos deuses da Antiguidade grega e romana. O rapsodo, levando suas produções de cidade em cidade, a elas ia "juntando", em diálogo, poemas e músicas dos diferentes lugares em que se apresentava. Já no século XII, poetas e músicos convergiam na figura do trovador, havendo uma produção literária majoritariamente oral, criada para ser acompanhada por instrumentos musicais. No Renascimento e no Barroco, além do poema, o texto dramatúrgico instigava a produção musical para fins de encenação, momento em que surgiu a conhecida ópera moderna, a qual mantém suas características de obra dramática musicada há quase 400 anos (cf. BRASIL, 2015, p. 12).

No século $\mathrm{XX}$, à luz das estéticas modernistas, o texto literário recebeu novas formas de influência da linguagem musical. É pertinente citar, a título de exemplificação, a obraMacunaíma, o herói sem nenhum caráter, de Mário de Andrade.O texto reproduz, em sua disposição narrativa, como salientado pelo próprio autor e pela crítica, a forma rapsódia. Tal forma, uma espécie de composição musical sem estrutura rígida, é caracterizada geralmente pelos processos de composição improvisada, porutilizar melodias pré-existentes dandolhes novo sentido conforme a vontade do compositor, e pela exploração de efeitos musicais que remetem a composições de caráter nacional e/ou regional.

Silviano Santiago (1989) também se debruça sobre as relações entre literatura e música ao propor uma análise de Clarissa, de Érico Veríssimo, na qual ele argumenta que, assim comoMacunaíma, o romance também reflete uma estrutura musical semelhante à rapsódia. Nele, Érico Veríssimo pretende "combinar em harmonia elementos heteróclitos, de tal forma que exista uma composição do todo que não seja mero produto de acúmulo" (SANTIAGO, 2002, p. 176). Estes rápidos exemplos, sem pretensão de traçar uma diacronia, apontam para uma constância da imbricação entre as duas formas artísticas.

O campo de estudos intermidiáticos, denominado melopoética - do grego mélos (canto) e poética -, compreende as relações entre literatura e música. Solange Ribeiro Ribeiro (2002) insere a melopoética em três categorias: estudos literários-musicais, quando o instrumental dos estudos literários são utilizados para a análise musical; estudos músico-literários, que promovem o movimento contrário, isto é, a musicologia fornece instrumental para a análise literária; estudos de forma mista, apoiados simultaneamente na musicologia e nos estudos literários. Mais adiante, evidenciaremos que o romance $O$ inverno e depois, de Luiz Antônio de
Assis Brasil, que será objeto deste trabalho, responde ao movimento dialógico da segunda categoria.

No contexto contemporâneo, a relação entre a literatura e a música se manifesta em formas variadas, com diferentes características, intenções, e abordagens. É comum encontrar escritores e músicos que se apropriam de elementos de outros segmentos artísticos, não só musicais, criando objetos que instigam a crítica a perseguir novos parâmetros e, mesmo, a redefinir áreas de conhecimento. A denominada área da Intermidialidade, - que também compreende as interações entre outras artes e mídias além da literatura e da música, tais como a pintura, o cinema, a fotografia etc., que podem "se situar nos níveis de produção, do artefato em si mesmo (a obra) ou ainda dos processos de recepção e conhecimento" (MOSER, 2006, p. 43), - traz aportes interessantes uma vez que atenta para a grande diversidade da produção contemporânea.A respeito dessas relações intermidiáticas, é evidente que a especificidade de cada arte envolvida em determinada interação contribui para o enriquecimento e, talvez, para o pleno entendimento do que se constrói a partir de tais diálogos.

Voltando-se para a relação dialógica entre literatura e música enquanto exemplo de intermidialidade, Wolf (1999) define dois tipos que ocorrem nas relações músico-literárias: a direta/manifesta e a indireta/velada.A intermidialidade direta/manifesta corresponde às relações em que ambas as artes envolvidas aparecem com o seu significante característico e permanecem distintas entre si, tal como na ópera, em que se pode distinguir o que é literatura/teatro e o que é música, embora ambas estejam envolvidas no mesmo processo artístico. Já a indireta/ velada corresponde às relações em que uma das artes envolvidas é a dominante do processo intermidiático, de modo que a outra se torna encoberta pela principal, como é o exemplo das ficções musicalizadas que, embora possam receber influências muito fortes da música, continuam sendo literatura. A respeito dessa ficção musicalizada como um exemplo da relação indireta/velada músicoliterária, Wolf (1999) afirma:

É necessário enfatizar que podemos falar de tentativas de 'musicalização' da literatura apenas se algum tipo de 'iconicidade' intermidiática - texto que imita música - ocorre numa obra literária. A musicalização da ficção é um caso especial de intermidialidade velada músico-literária que envolve o modo da imitação. Mais precisamente, ela consiste na formatação do 'discurso' de um romance ou conto (afetando, por exemplo, o material linguístico, a disposição ou a estrutura da narrativa, e as imagens utilizadas) e, em alguns casos, também da história (o conteúdo da narrativa), de tal modo que similaridades ou analogias 'icônicas' verificáveis [...] com (uma peça de) música ou com 
os efeitos por ela produzidos surjam no texto (ou em partes dele). Como resultado, o leitor tem a impressão de que a música está envolvida na significação da narrativa $[\ldots .$.$] e que a presença da música pode ser$ indiretamente experimentada durante a leitura (WOLF, 1999, p. 48, tradução nossa).

Tomando como pertinentes as distinções de Wolf sobre os tipos de intermidialidade, podemos considerar que o romance $O$ inverno e depois, de Luiz Antonio de Assis Brasil (2016) apresenta os traços característicos da intermidialidade indireta/velada músico-literária, constituindo um claro exemplo do que seria essa ficção musicalizada. O romance sofre notórias influências do discurso musical tanto no plano do material discursivo (a estrutura do romance se assemelha a uma forma musical), quanto no plano do conteúdo narrativo (a música também aparece no romance com o papel de afirmação da existência e no de conferir humanidade e identidade ao personagem principal, além de se relacionar com os sentimentos, a memória, a tradição, a família e o espaço).

Publicado em 2016, O inverno e depois, $20^{\circ}$ romance do gaúcho Luiz Antonio de Assis Brasil, narra a história de Julius, um violoncelista da Orquestra Sinfônica Municipal de São Paulo. O personagem decide passar um período isolado na Estância Júpiter, localizada na sua cidade natal, no interior sul-rio-grandense, a fim de estudar o difícil Concerto para violoncelo e orquestra, de Antonín Dvořák, cuja execução o obseda desde a juventude. No entanto, a busca pela musicalidade da peça de complexa execução excede o campo técnico da música e torna-se alvo de outros dois grandes conflitos ainda não resolvidos: o não enfrentamento com a meia-irmã Antônia e a brusca interrupção de um relacionamento amoroso, sua grande paixão da juventude.

É interessante a associação entre a construção da identidade do personagem principal, Julius, e sua construção enquanto músico. Na infância, quando vivia no Rio Grande do Sul com os pais, ganhou de sua tia um violino branco que o despertou para a existência do mundo musical. Na adolescência, já vivendo em São Paulo com a tia, preencheu com a música grande parte da sua "alma órfã" ao estudar piano e, posteriormente o violoncelo, instrumento que escolheu seguir tocando profissionalmente. Na juventude, mudou-se para Würzburg, onde se especializou numa escola de música e viveu a paixão de sua vida: relacionou-se com Constanza Zabala, uma aluna uruguaia, estudante de flauta no mesmo conservatório na cidade alemã. De volta ao Brasil, tornou-se um violoncelista respeitado, mas não o solista que sonhara, uma vez que se julgava incapaz de executar em público o Concerto que tanto o fascinava. No plano presente da narrativa, o retorno do personagem ao pampa, às origens, significa encarar um passado ainda não resolvido, que necessita de enfrentamento e reconciliação.

A intermidialidade indireta em $O$ inverno e depois se apresenta, primeiramente, na estrutura narrativa. São três os espaços-tempos em que a história se passa: a infância de Julius - uma parte no Rio Grande do Sul, outra em São Paulo; a juventude, em Würzburg; e a vida adulta, no tempo presente, com foco no seu retorno à casa da infância.

Há, no texto, muitas evidências da presença da estrutura musical do Concerto para violoncelo, de Antonín Dvořák, na configuração do romance, considerando-se, igualmente, a importância de tal peça para a estrutura de significação da narrativa: assim como há três espaços-tempos no romance, o concerto é divido em três movimentos (Allegro, Adagio ma non troppo e Finale). Cada parte da narrativa de Assis Brasil se assemelha a cada um dos movimentos do concerto, tanto em questões técnicas (andamento, tonalidade, sequência narrativa), quanto na intenção musical do concerto (efeitos pretendidos a partir de determinadas construções musicais). No entanto, é importante salientar que essa "imitação" do concerto não se dá de maneira rígida e claramente identificável numa primeira leitura, como, aliás, é corroborado pelo próprio autor em um ensaio de 2015:

O texto literário é, de todas as artes, o mais suscetível de ser influenciado por outras formas de expressão, e hoje é possível afirmar que os movimentos da formasonata têm muito a ver com os capítulos ou segmentos da narrativa literária. É claro que não se fala de uma influência direta, rígida, e constatável à primeira leitura: trata-se mais de uma espécie de atitude narrativa que segmenta o texto em fragmentos que, muitas vezes, alternam as expressões do introspectivo com o extrospectivo, o cômico com o sério, a ação com a reflexão (BRASIL, 2015, p. 12).

Destaca-se, aqui, que a presença da música na literatura de Assis Brasil não se restringe ao livro em análise, mas se faz notar em praticamente toda a refinada obra do escritor, moldando-se ora como material temático, ora como jogo metafórico entre o campo discursivo musical e a sequência narrativa, ora como analogia estrutural entre música e palavra, além de poder conferir "o andamento rítmico ao período gramatical" (BRASIL, 2015, p. 11), nas palavras do próprio escritor. Tem-se, por exemplo, numa série de quatro romances, Visitantes ao Sul, a música com um papel fundamental de articulação, conforme Pelinser e Cury (2014), uma vez que as narrativas que compõem a série funcionam como melodias em contraponto de uma mesma música: "É à imagem do tema e suas variações que recorre para definir 
o conjunto, reiterando a presença do campo semântico musical como articulador dos significados de Visitantes ao Sul" (PELINSER; CURY, 2014, p. 379). Outros livros do escritor também apresentam a música como elemento principal, podendo-se citar Concerto Campestre (1997), como está sugerido desde o título, e $O$ homem amoroso (1986), novela que discorre sobre as vicissitudes de um violoncelista gaúcho, melancólica narrativa também tingida por traços biográficos.

$\mathrm{Na}$ tetralogia referida, Visitantes ao sul, de resto, é notável o diálogo entre diferentes produções culturais acompanhado de uma instigação à reflexão sobre os limites de representação e sua inter-relação histórica. Assim, em $O$ Pintor de retratos, entre outras dimensões, evidenciam-se os impasses sentidos pelos pintores com o advento da fotografia; em $A$ margem imóvel do rio, elege-se o discurso da história e a constatação de seus limites enquanto reprodução do real vivido e enquanto fidedigna guardiãda memória; em Música perdida, como já se torna evidente pelo título, imbricam-se um melancólico discurso de recuperação memorialística e a busca pela música, discursos musical e de memória, ambos, escandindo a melodia da vida do protagonista; e Figura na sombra, em que se relacionam literatura e discurso da ciência. A tetralogia, finalmente, recupera os espaços do sul do país, da província do Rio Grande do Sul, espaço geográfico e afetivo sempre encenado nas obras de Assis Brasil.

Antes, porém, das aproximações entre $O$ inverno $e$ depois e o referido concerto de Dvořak, é relevante pensar também nas duas "narrativas" como obras com traços de autoficção e no contexto em que foram criadas. A história de $O$ inverno e depois se aproxima de experiências pessoais do autor: assim como o personagem Julius, Luiz Antonio de Assis Brasil também foi violoncelista profissional e morou um período na Alemanha. Daí a intimidade do escritor com o árduo processo do personagem para se tornar um músico, a firmeza ao "denunciar" as relações de competição e rivalidade que existem no interior das orquestras e a precisão repassada por delicada sensibilidade ao descrever Würzburg, de modo a que o leitor vá construindo uma imagem da cidade alemã onde transcorre parte importante da trama. "Não sei escrever sobre o que eu não conheço" (GRUNER, 2016) é a resposta dada pelo autor, em entrevista, ao ser questionado sobre a sua similaridade com o personagem violoncelista e o fato de ambos, autor e personagem, terem vivido na Alemanha. Ressalte-se, ainda, neste sentido, a intensidade imagética das descrições da cidade alemã, intensidade, de resto, muito própria ao sofisticado estilo do escritor gaúcho.

Quanto ao Concerto para violoncelo e orquestra, também ele apresenta forte teor autobiográfico. Antonín
Dvořák, nascido em 1841, na atual República Checa, desde cedo revela talentos musicais. Em 1891, com sua carreira de compositor já consolidada, aceita o convite para dirigir o Conservatório de Nova York e lecionar composição, mudando-se para os Estados Unidos com a esposa e dois filhos. Permanece no país até abril de 1895, após enfrentar diversos problemas, inclusive financeiros, "sob uma pesada atmosfera que influenciava também o seu trabalho criativo" (MOTA, 2015, p. 54). Durante esse período nos EUA, Dvořák desenvolveu um estilo de composição americano devido à proposta didática do Conservatório de Nova York, o que afetou, em parte, algumas de suas composições.

O Concerto para violoncelo e orquestra foi composto entre 1893 e 1895. Mota (2015) define a obra como um "concerto de regresso a casa", uma vez que o uso do estilo americano na composição foi reduzido, voltando a ganhar mais espaço o estilo nacionalista checo, certamente porque o compositor sentia falta de sua terra natal e do seu círculo social: "na sua vertente emocional, o concerto é nutrido pela saudade do lar, e pelas memórias do seu país e do seu povo" (ŠOUREK; SAMSOUR, 1956, p. 175 apud MOTA, 2015, p. 65). Além de toda a nostalgia da terra natal e de ser marcada pela memória, a peça ainda tem outra motivação: o amor não resolvido de Dvořák por sua cunhada Josefina, cuja morte era iminente no período da composição do concerto, o que levou o compositor a sinalizar, especialmente no segundo movimento da peça, uma homenagem à mulher amada. Mota (2015) registra esse caso de amor, parafraseando o comentário da violoncelista Maria de Macedo em entrevista:

Josefina é sempre o motivo de inspiração [paraDvořák]. [...]Uma coisa é o amor directo, outra o que serve só de inspiração. [...] Talvez o mais sublime do amor possa ser exactamente a inspiração. [...] É bastante óbvio que esta dimensão do amor existe na vida de Dvořák, pois ao longo da sua vida regressou por diversas vezes às canções que escreveu no princípio da carreira, precisamente num momento em que estava muito ligado a Josefina [...] Este regresso é como querer ter a presença da sua amada através daquelas canções durante toda a sua vida (MOTA, 2015, p. 117).

Resumindo tais observações, talvez se possa afirmar que o Concerto para violoncelo tem como base dois pontos de motivação: o desejo de regresso a casa e um amor não resolvido. Não parece ser mera coincidência que O inverno e depois também tenha tais pontos centrais na sua construção. O personagem Julius, ao decidir executar a peça que há muito o obseda, regressa a casa da infância em busca de um ambiente propício para o estudo, espaço esse que o coloca frente a memórias que ainda geram perturbação. As memórias de sua terra, das pessoas com as 
quais conviveu, as lembranças da infância suscitadas pelo regresso à casa paterna, reavivam as experiências, tanto as felizes como as traumáticas. O passado, assim recuperado, ainda que não despido de contradições, necessita se ver conciliado ao tempo presente da narrativa. Além, é claro, da memória do período passado em Würzburg e da marcante relação amorosa com Constanza Zabala, relacionamento bruscamente interrompido.

O regresso a casa também se faz presente em outro ponto importante da narrativa. Quando o personagem morava na Alemanha, sentia, além de uma nostalgia intensa do país de origem, um sentimento de não pertencimento, como é possível notar no trecho em que Julius, embora deslumbrado pela paisagem da cidade a sua volta, não consegue senti-la como parte integrante da sua identidade:

Era uma beleza [a cidade Würzburg] de que ele, contudo, não conseguia se apropriar. Algo devorava seu espírito e, caso acreditasse nela, também sua alma. Por um momento desejou ser mais um habitante de Würzburg, porque uma coisa é sofrer no estrangeiro, outra é sofrer na cidade em que se nasceu, onde o conhecimento íntimo do ar, das ruas e praças e do próprio ritmo do tempo colaboram para amenizar a dor (BRASIL, 2016, p. 41).

A passagem evidencia, entre outras, a condição de persistente sofrimento do personagem, agravada pela distância da terra natal. E é em meio à situação conflituosa vivida na cidade de Würzburg que acontece a sua história de amor. O violoncelista se envolve com Constanza e ambos, a par seus dramas pessoais, entregam-se a viver uma história de amor: "Ela me ama à beira do desastre, talvez a ela também nada mais reste" (BRASIL, 2016, p. 72) é a melancólica conclusão do protagonista. Tal como acontece com Dvořák e sua cunhada Josefina, a história de amor de Julius e Constanza é suspensa após inúmeras crises, o que não impediu que sua marca continuasse a acompanhar o violoncelista como uma memória inquieta, própria de uma situação mal resolvida.

À vista disso, voltamos para as similaridades que se estendem da feição autobiográfica e das temáticas de regresso a casa e amores suspensos, como já dito anteriormente, para as semelhanças entre as estruturas narrativas de ambas as obras. O Concerto para violoncelo, reitere-se, é divido em três movimentos: Allegro, Adagio ma non troppo e Finale, que são partes melódicas diferentes em seus formatos, nas suas intenções, no modo como os instrumentos dialogam entre si. Embora tenha sido escrito em 10 capítulos, podemos também extrair do romance $O$ inverno e depois três partes principais que se articulam no espaço e tempo narrativos. Cada espaço-tempo do romance se assemelha a um movimento do concerto, como já colocado anteriormente. Mas não somente isso, uma vez que a arquitetura da narrativa se sofistica pelo entrelaçamento, no decorrer dos dez capítulos, das três estruturas características de cada movimento da peça de Dvořák. A estrutura da formasonata, oriunda do primeiro movimento do concerto, reverbera nas passagens da narrativa que encenam a infância do personagem Julius. A estrutura de forma ternária, proveniente do segundo movimento, espelha-se nas partes relacionadas ao que Julius viveu na Alemanha. E, finalmente, a estrutura da forma rondó, originária do terceiro movimento, guarda correspondência com o tempo presente da narrativa. Isso se tornará mais claro a seguir, com análise individual das semelhanças entre cada movimento e a estrutura espaçotempo.

O primeiro movimento do Concerto para violoncelo, Allegro, é estruturado na forma de sonata clássica, também chamada de forma de primeiro movimento, sonata-allegro ou, simplesmente, de forma sonata. Tal forma consiste na utilização, no decorrer do movimento, de dois materiais melódicos distintos denominados temas, uma espécie de refrão que é moldado e modificado de acordo com a necessidade e vontade do compositor, sendo que cada tema apresenta uma tonalidade diferente. Tonalidade se refere, basicamente, a um sistema de utilização de notas que determinarão a característica de determinada música, baseando-se em torno de uma nota principal, como se fosse a sua cor, a sua essência. Então, na forma sonata, necessariamente, existem dois temas, cada um com a sua tonalidade e característica, a serem trabalhados numa sequência narrativa que se estrutura como exposição, uma vez que ambos os temas são aí apresentados de maneira contrastante. Em seguida, tem-se o desenvolvimento, parte em que os temas são remodelados e reestruturados, entrando em conflito, e a reexposição, uma espécie de recapitulação do material usado na exposição, em que há a resolução da tensão criada entre os dois temas. Finalmente, a coda, uma seção de encerramento do movimento.

A forma como Assis Brasil estrutura a narrativa da infância de Julius, a partir de flashbacks, se assemelha a como Dvořák trabalha com os elementos musicais da forma-sonata. O primeiro movimento do Concerto para violoncelo e orquestra possui dois temas contrastantes: "um tema viril e rítmico e um outro melódico, de certa forma feminino" (MOTA, 2015, p. 101) que são expostos tanto pela orquestra, quanto pelo violoncelo solo. Já o desenvolvimento do concerto somente apresenta o material do primeiro tema, "o qual sofre todo tipo de transformações e, às vezes, evolui para conjuntos inteiros de variantes melódicas" (SUPKS, 2013, tradução nossa). A reexposição no concerto se dá com material majoritariamente do segundo tema, numa seção que 
"parece expressar um estado de ser confiante, majestoso e alegre" (BIAN, 2017, p. 23, tradução nossa). O primeiro movimento termina com uma coda deslumbrante recorrendo principalmente ao material do primeiro tema, numa tonalidade que expressa festividade e alegria.

Em $O$ inverno e depois, a infância de Julius ressoa em seu imaginário como um período melancólico e traumático devido ao caos estabelecido em sua casa após o nascimento da sua meia-irmã, Antônia, filha de seu pai com a amante. Tendo em vista a relevância dessa personagem para a trama, para o dilema que atormenta o protagonista do romance, podemos considerar que cada tema do concerto é representado no romance pelos dois personagens principais: Julius - o primeiro tema, e Antonia - o segundo tema, uma vez que todos os conflitos, dramas e cenas relacionadas à infância de Julius se dão em torno desses dois personagens, assim como, no Concerto, a construção do primeiro movimento se dá em torno dos temas. Tudo isso muito embora a personagem Antônia só apareça em alguns pontos chaves da narrativa.

$\mathrm{Na}$ mesma sequência de diálogo com o Concerto para violoncelo, a seção do romance que aqui chamamos exposição apresenta o primeiro tema, isto é, Julius. É feita uma abrangente descrição do personagem, desde o seu nascimento "numa noite de minuano [...], tal como nos romances" (BRASIL, 2016, p. 23) até o período que antecede sua viagem a Würzburg, quando se preparou para prestar o exame na Alemanha. A origem duplamente marcada: pelo minuano, vento frio e cortante característico da região sul do país, e pela literatura. Esta última é lembrada pela presença do vento minuano em muitos textos da literatura sul-rio-grandense, como no clássico $O$ tempo e o vento, de Érico Veríssimo e na obra do próprio Assis Brasil, como no extraordinário romance A margem imóvel do rio.

No concerto, a exposição do primeiro tema sugere uma "canção de lirismo extático e profundamente triste" (BIAN, 2017, p. 23, tradução nossa). Profundamente triste e num lirismo em êxtase se constituem, também, as primeiras descrições da história de Julius: o menino "precoce, mas de um jeito errante" (BRASIL, 2016, p. 23), que teve que lidar com a saída traumática do Rio Grande do Sul, da qual "ele se recorda com dor e angústia" (BRASIL, 2016, p. 24), com a perda do pequeno violino branco e com a morte dos pais num acidente de carro, levando-o a depositar no violoncelo e, portanto, na música, "todos os matizes de sua alma órfã" (BRASIL, 2016, p. 27)

A perda do violino branco, em larga medida simbolizando a passagem traumática da infância para a vida adulta, duplica-se na narrativa no abandono da casa paterna e na morte inopinada dos pais. Na verdade, a cena adquire a estrutura de repetição própria do trauma. No romance, já na Alemanha, a cena mais uma vez retorna, com muito impacto em Julius, quando Ishiro, filho de apenas seis anos do professor Bruno Brand, se apresenta para os alunos do mestre.

Ishiro levantou-se com demorada solenidade, pegou o pequeno estojo da cadeira ao lado, abriu-o e dali retirou um violino de tamanho reduzido - e branco. Julius prestou atenção. Não era o momento de sentir nada além de uma indulgente curiosidade e, no entanto, foi atingido em cheio por uma perturbadora reminiscência de sua própria infância, irredutível à organização em palavras (BRASIL, 2016, p. 143).

O próprio narrador chama a atenção para a reminiscência traumática, definindo-a como aquela que não é passível de enunciação. Além disso, lembre-se de que, na trama, o professor de violoncelo Bruno Brand exerce, num certo sentido, a função de duplo do pai do protagonista. Como este último, também o professor vem a morrer subitamente, deixando o aluno "novamente" órfão. A cena do violino volta, ainda, quando logo depois da apresentação de Ishiro, conversando com uma amiga da escola de música, Julius reitera sua importância:

Eu já tive um violino de brinquedo, branco, quando era criança. Com ele fiz uma audição fantasiado de samurai. Quando Ishiro o tirou do estojo, era como se fosse o meu violino. Eu perdi o meu quando tinha a idade de Ishiro (BRASIL, 2016, p. 144).

Muitos anos depois, ao reencontrar a mesma amiga, fica sabendo que Ishiro Brand se tornara um grande e reconhecido violinista e melancolicamente conclui para si mesmo: "Ishiro soube o que fazer com seu violino branco, enquanto ele, que também tivera um violino branco, não se transformara no concertista que um dia imaginou ser" (BRASIL, 2016, p. 250).

O segundo tema, no concerto, é exposto primeiramente "pela trompa em pianissimo, como um sussurro misterioso" (POMBO, 2007). Do mesmo modo, Antônia é inserida na narrativa, após a exposição do primeiro tema, de maneira "pianíssima", rápida e misteriosa. A partir da visão de Julius, é traçado seu perfil e é feita uma síntese de algumas passagens da sua história. O narrador também pontua o contraste, assim como no Concerto de Dvořák, entre ambos os temas a partir do conflito que há entre os dois irmãos: "Ele não tem espaço interior para nele acrescentar uma meia-irmã" (BRASIL, 2016, p. 33). Saliente-se, igualmente, o insulamento afetivo do personagem, refratário à abertura ao outro. Além disso, foi a descoberta da existência desta irmã, nascida fora do matrimônio, a causa da saída da família da casa da infância. 
O desenvolvimento da narrativa, assim como no concerto de Dvořák, apresenta o material do primeiro tema, isto é, o personagem Julius e sua história. Pode-se considerar como partes do desenvolvimento: a cena na qual, por meio da memória, Julius presentifica a situação traumática que o obrigou a sair do Rio Grande do Sul, deixando para trás a casa paterna: "Eis a memória: aqui, num fim de almoço, começou a caótica transferência da família para São Paulo" (BRASIL, 2016, p. 103). Também a passagem que exibe o protagonista relembrando os pais, a cena primária da infância ao explorar, agora como homem adulto, os cômodos da casa:

\begin{abstract}
Julius se aproxima da penteadeira. Seus passos fazem ranger as tábuas do assoalho. [...] No grande espelho basculante e oval ele vê refletido aquele homem maduro, de óculos, que quer disfarçar sua estranheza ao se enxergar de poncho. Ao lado do espelho, uma pequena foto. É ele, criança. [...] Nesta mesma foto, atrás de si, de pé, está o pai Latinista, com um lenço branco no pescoço e botas de fole [...]. Já pensa na mãe. Sempre que a traz à lembrança, nunca é de maneira completa (BRASIL, 2016, p. 112-113).
\end{abstract}

As passagens, carregadas das recordações da infância, transportam o peso da simbologia atribuída por Gaston Bachelard à casa paterna. Para o filósofo francês, a casa é "o nosso primeiro universo". Tanto o seu interior, como suas partes, simbolizam os diversos estados da alma não importando os detalhes de riqueza ou de pobreza. Ainda segundo Bachelard, a casa natal fisicamente está inscrita em nós e é a ela que retornamos quando sonhamos ou quando nos empenhamos em redefinir o nosso eixo interior.

O passado, presente e futuro dão à casa dinamismos diferentes, dinamismos que frequentemente intervêm, às vezes se opondo, às vezes estimulando-se um ao outro. A casa, na vida do homem, afasta contingências, multiplica seus conselhos de continuidade. Sem ela, o homem seria um ser disperso. Ela mantém o homem através das tempestades do céu e das tempestades da vida. Ela é corpo e alma. É o primeiro mundo do ser humano. Antes de ser "atirado ao mundo" (...) o homem é colocado no berço da casa. E sempre, em nossos devaneios, a casa é um grande berço (BACHELARD, 1974, p. 358).

Como registra o estudioso francês, no entanto, as ideias de proteção, estabilidade e sossego ligadas à casa associam-se da mesma forma os seus opostos, transformando-a num símbolo contraditório. Recuperada imageticamente em sonhos e lembranças, ficcionalmente reescrita pelas memórias, é a casa que abriga os nossos devaneios, nossos sonhos, mas também o inconsciente, nossos medos e contradições. Assim,a volta de Julius à Estância Júpiter, revisitando lugares tantoas lembranças dos pais, como aquelasfantasiosas que o assombravam em criança.

Outra cena do romance que pode ser incluída no que aqui se denomina desenvolvimento, mais uma vez figurada com recursos da memória, é aquela em que Julius recorda um episódio da infância, memória desencadeada pela visualização de um fogo que, conforme diz a tradição de sua terra, continua a arder depois de séculos. "O pavor da infância, agora, é um temor difuso por alguma desgraça sem data para acontecer, mas contra a qual ele não pode fazer nada" (BRASIL, 2016, p. 195). São, pois, várias as cenas que afloram na narrativa, desencadeadas pela memória involuntária de Julius e marcadas com o peso de sentimentos melancólicos e fatalistas do personagem.

Ao material utilizado por Dvořák no concerto para a apresentação do segundo tema, uma reexposição, corresponde à presença de Antônia no livro de Assis Brasil. É interessante que, nas cenas do livro consideradas como desenvolvimento, a presença da irmã, bem como as memórias de Julius a ela relacionadas, como já se disse, são poucas. E assim como no Concerto o segundo tema volta majoritariamente na reexposição, a presença de Antônia na narrativa ocorre em momento já bem avançado da trama, em que, finalmente, Julius a reencontra após anos sem vê-la: "A mulher sorri. Ele sabe: enfim, ela" (BRASIL, 2016, p. 261). Nessa reexposição, Julius traz à memória os diversos conflitos relacionados com a existência de Antonia e, finalmente, consegue estabelecer um diálogo com a irmã. Tudo isso abre o caminho para a coda, um encerramento festivo, tal como no Concerto, dessa parte da vida de Julius. Ela ocorre quando Julius pede perdão à irmã e sente que só então essa parte do passado não mais o assombrará:

- Antônia, [...] Não vou conseguir explicar. O importante é que você saiba disso. [...] Vencendo um tabu, ele se vê dizendo: - Preciso te pedir que me perdoe. [...] Por todos esses anos de perseverança. Você nunca desistiu. Você veio à minha procura. Você achou um motivo. [...]

- Nunca perdi a esperança de que um dia, muito no futuro - ela gagueja -, nós nos encontraríamos.

- Este é o dia, Antônia, - Ele põe o braço sobre os ombros dela, e a traz junto a si (BRASIL, 2016, p. 323-324).

O "primeiro movimento da narrativa" de Assis Brasil corresponde ao que se é esperado na estruturação da forma sonata, sendo que tanto os temas contrastantes, como o conflito entre áreas tonais podem ser caracterizados como a questão central do movimento. No que se refere a esse conflito, Solange Oliveira (2002) afirma que 
a forma sonata não se caracteriza tanto pelo tema apresentado na exposição e posteriormente desenvolvido, mas por uma instabilidade inicial, sob a forma de duas áreas tonais conflitantes. Essa tensão acentua-se durante o desenvolvimento, que não apenas entrelaça os temas, mas, sobretudo, aventura-se por áreas harmônicas mais distanciadas. A recapitulação [reexposição] resolve essas tensões eliminando o conflito de tonalidades. [...]. Tem-se, assim, uma estrutura ABA', representando instabilidade/intensificação da instabilidade/resolução (OLIVEIRA, 2002, p. 132-133).

A instabilidade, metaforicamente associada às passagens iniciais em que o personagem Julius tem uma relação não resolvida com a irmã Antonia. Aintensificação da instabilidade, associada aos trechos em que Julius volta à casa da infância e os sentimentos negativos em relação à irmã são nutridos pelas memórias do passado. Aresolução, associada às partes em que Julius consegue estabelecer um diálogo com Antonia, a possibilidade da reconciliação entre ambos e a expectativa de uma nova amizade.

Finalizado o primeiro movimento, o Concerto caminha para o segundo: Adagio, ma non troppo. Com esse movimento se relacionam, no romance $O$ inverno $e$ depois, as partes da narrativa enfocando o período em que Julius passou em Würzburg e a história de amor vivida com a flautista uruguaia. A estrutura desse movimento no concerto é uma forma ternária, que está dividida em três seções (ABA'), sendo similares às seções A e A', enquanto a seção $B$ apresenta um contraste, um novo material melódico, em relação às outras. A seção $\mathrm{A}$ traz elementos do primeiro tema do primeiro movimento, mas de maneira modificada, e se reveste de "um caráter pacífico e silencioso semelhante a uma canção de ninar" (BIAN, 2017, p. 24, tradução nossa). Já na seção B, o compositor introduz uma nova melodia pacífica e melancólica, com citação de uma parte de Lasst mich allein (Deixe-me só), Lied por ele composta em 1887-1888. A seção A' é o encerramento do movimento e apresenta um "carácter de resignação, de aceitação pacífica de todos os acontecimentos" (MOTA, 2015, p. 153).

Assim como são três as seções presentes no segundo movimento do Concerto, são três os capítulos da narrativa de Assis Brasil que se passam inteiramente em Würzburg: os capítulos 2, 4 e 6 . Nos capítulos 2 e 6 , a narrativa tem a mesma temática característica (tal como são as seções A e A' do concerto): a história de Julius a partir do fim da sua estadia em Würzburg, quando ele conhece Constanza, passando pelas cenas em que os dois se envolvem amorosamente e fechando-se com o dramático final do relacionamento.

O capítulo 4 funciona como o contraste temático da estadia do violoncelista na Alemanha, intercalado, tal como ocorre na seção B do concerto, com a narrativa da história de Julius antes de se envolver com Constanza, desde sua chegada à Alemanha, o processo de adaptação na cidade, o estabelecimento de relações sociais, a morte chocante do seu professor de violoncelo e, sobretudo, a ousada decisão, que permeia toda a história, de executar o Concerto para violoncelo e orquestra, de Dvořák.

Além disso, a semelhança entre a parte da narrativa de Julius na Alemanha e esse movimento do concerto também se dá pelas intenções emocionais e pelas temáticas propostas por ambos como já se disse: a nostalgia da terra natal, a expressão de lamento e dor do protagonista (Julius/ violoncelo solo) e as fortes sensações de amor, paixão e solidão. Veja-se como exemplo a cena em que Julius se vê desacreditado após a morte de seu professor e a despedida de uma amiga: "O que Julius sentia era pesar, revolta e abandono. Em poucos dias ele perdera duas pessoas que lhe davam a certeza de que era ainda possível acreditar na Arte e, por extensão, no ser humano" (BRASIL, 2016, p. 162). Expressão, melancólica embora, da importância da música na obra de Assis Brasil e do caráter humanista do seu projeto literário e inovador da sua escrita, tão marcantemente contemporânea e, ao mesmo tempo, fiel à forma clássica do romance, escrita que prende o leitor nas malhas de uma trama bem construída.

Já no início do segundo movimento do Concerto, há uma expressão lírica de nostalgia, "como se Dvořák reagisse, por meio de uma lenta melodia, à excitação do 'Novo Mundo', com os instrumentos de sopro entoando solenemente a melancolia do tema principal" (SEROTSKY, 2009). Esse sentimento é expresso em forma de um lamento, um "gesto musical característico que existe desde o Barroco como 'forma de expressar a dor"” (MOTA, 2015, p. 117). É no início de O inverno $e$ depois que a sensação de nostalgia da terra natal é sentida por Julius: o personagem encontra-se desolado e solitário após ter decidido voltar para o Brasil, sem ter conseguido apropriar-se da beleza da cidade e sem ter alcançado o padrão deexecução musical exigido pela instituição alemã. Em meio a uma reflexão melancólica e fatalista, o narrador pontua: "Começava, aos poucos, a sentir a estranha paz dos que chegam à conclusão de que, se a queda no precipício é iminente, a maneira para acabar logo com a agonia é projetar-se nele" (BRASIL, 2016, p. 44).

Essa dor presente na história de Julius também se assemelha à dor representada no segundo movimento do concerto de Dvořák, uma dor que, embora excessiva, "certamente não terá qualquer dimensão de tragédia" (MOTA, 2015, p. 117). Ou seja, a dor representada nesse ponto das narrativas difere daquela própria ao luto, por exemplo, sendo, antes, uma dor melancólica e nostálgica: "Para culminar, sentia falta da temperatura de São Paulo 
no verão, no corpo abrangido pelo calor, da agitação das ruas. Sentia falta, também, do conforto que era falar a própria língua" (BRASIL, 2016, p. 125).

Registrando o impasse em que se encontra o estrangeiro, sempre entre duas línguas, Julia Kristeva, ela própria búlgara entre franceses, diz sobre a situação do exilado:

Não falar a língua materna. Habitar sonoridades e lógicas cortadas da memória noturna do corpo, do sono agridoce da infância. Trazer em si, como um jazigo secreto ou como uma criança deficiente, benquista e inútil, essa linguagem de outrora, que marcha sem jamais abandoná-la (KRISTEVA, 1994, p. 22).

"O conforto de falar a própria língua" como o desejo de retomar a língua materna, cortada da memória do corpo pela situação do exílio.

Ainda sobre o segundo movimento do concerto, é importante salientar que ele apresenta, em toda sua extensão, uma "constante dualidade de sentimentos" (POMBO, 2007) que pode ser observada no contraste das cargas emocionais dos dois temas principais: o primeiro, de feição serena e pacífica, e o segundo, de feição dramática e poderosa. Tais contrastes são expressos também no romance, sobretudo no relacionamento entre Julius e Contanza, que foi alvo, mesmo num período relativamente curto, de sentimentos intensos e opostos, oscilantes entre amor e ódio, desejo e apatia, entusiasmo e desinteresse:

\begin{abstract}
A complexidade amorosa de Constanza o conduzia a um domínio cada vez mais insólito, e essa história iria levá-lo a uma voragem devastadora, porque um homem não pode conviver com tantas circunstâncias. Era preciso dar um fim a essa ópera de mau gosto. 'No entanto, não posso viver sem ela' (BRASIL, 2016, p. 228).
\end{abstract}

Partindo para o terceiro e último movimento do Concerto para violoncelo, no Finale, Allegro moderato, tem-se uma narrativa estruturada na forma rondó. "Em uma forma rondó, o tema principal (A) continua sempre retornando, existindo porém seções contrastantes $(\mathrm{B}, \mathrm{C}$ etc.) entre cada retorno e a anterior" (BENNETT, 2007, p. 51). A esse movimento, associamos o presente da narrativa de Julius, construída a partir da sua viagem de volta à Estância Júpiter a fim de encontrar paz para estudar o concerto. A abordagem desse terceiro movimento no concerto "se dá num contexto de "mover-se da escuridão para a luz', o que reflete a alegria de Dvoŕák por seu retorno definitivo à sua terra natal: o último movimento do concerto foi escrito poucas semanas antes de sua partida de Nova York" (SUPKA, 2013, tradução nossa).
Contexto semelhante pode ser percebido no texto de Assis Brasil. Quando Julius, ainda na Alemanha, decide estudar o Concerto para violoncelo, a intenção é de que consiga "contrariar as próprias inseguranças" (BRASIL, 2016, p. 148), e a sua execução seria algo que lhe conferiria dignidade, libertando-o de uma dívida como passado, podendo, a partir daí, assumir a própria história. Ressalte-se que Julius não conseguira executar publicamente o concerto na sua primeira tentativa, ainda na Alemanha, devido, sobretudo, à instabilidade emocional. Tal fato o leva a abandonar Würzburg, vazio de tudo, inclusive de si mesmo:

Tentava gravar na memória tudo que lhe acontecera e que ele chamaria dali por diante de meu fiasco. Isso foi tudo. Se a falta de talento já o decidira, o dia de hoje impunha o retorno ao Brasil. Ninguém se recupera depois que lhe acontece algo assim. Agarrara-se a Dvořák como a uma salvação, e agora nada mais lhe restava (BRASIL, 2016, p. 170).

De volta ao Brasil, conseguiu tornar-se um violoncelista respeitado. Seus pensamentos, porém, constantemente passaram a convergir numa visão sombriadesi mesmo e de sua vida: "Minha audácia é mais ou menos. Minha vida é mais ou menos" (BRASIL, 2016, p. 91). Podemos considerar, então, que o personagem entra numa espécie de "escuridão", sendo um homem saudoso e que, melancolicamente, se considera incompleto. $\mathrm{O}$ regresso à casa da infância para estudar o Concerto, marcado já nas primeiras páginas do romance, bem como toda sua trajetória até finalmente conseguir dominar o violoncelo e executar a peça - como exposto no último capítulo também representam, por assim dizer, uma passagem da "escuridão para a luz", uma vida que ganha, de fato, um significado, uma história.

Como já dito anteriormente, o terceiro movimento do Concerto é uma forma rondó, dividida em cinco seções: ABA'C'A", sendo B e C seções contrastantes. A narrativa de Julius, com foco no tempo presente, também se assemelha a essa forma. As seções A, A' e A', transpostas para a narrativa, são as partes em que Julius viaja e se hospeda na Estância Júpiter, enquanto as seções B e C são as partes intercaladas na narrativa que, mesmo situadas no presente, parecem ter uma importância maior para as conexões temporais de toda a história.

Sendo assim, a seção A se localiza no primeiro capítulo (intercalada por lembranças da infância), em que é narrada a desventura de Julius ao ter sua mala extraviada, e a viagem de carro de Porto Alegre até a Estância Júpiter. A seção B se localiza no terceiro capítulo, quando Julius se depara com a casa da infância e se sente estrangeiro no seu próprio lar, na sua própria memória. Nessa parte, o contraste temporal que atravessa toda a 
narrativa é introduzido: é o Outrora, algo que rompe com a concepção tradicional de espaço-tempo ao ser evocado junto às sensações do passado que construíram a identidade do personagem:

Ele [Julius] quer compreender este instante em que ensaia a elusiva sensação de que não apenas retorna ao pampa [...]. O sentimento é mais raro porque, se ele veio apenas à busca de um espaço para estudar o concerto de Dvořák, eis que se defronta com um tempo, impossível de ser medido em anos, séculos ou milênios, pois sobrevive uma época para além do pretérito imediato de uma vida, e que apenas a palavra pode expressar: é o Outrora. Nunca disse essa palavra, nunca a escreveu, jamais pensou nela; apenas a encontrava nos romances e poemas românticos, como uma expressão de duvidosa sentimentalidade. [...] Mas o outrora está aqui, nestes campos e animais, e é feito de tudo que habita o domínio da lenda, que marcou a vida dos que já morreram e que ainda existe a comandar os vivos e os que já morreram [...] Se o passado resulta de uma lembrança, o Outrora não pode ser lembrado, apenas evocado (BRASIL, 2016, p. 87).

A partir de então, o Outrora passa a ser evocado, nas entrelinhas, em todo tipo de situação que ameaça Julius a ser banido da sua própria memória. "Ele, na refinada ordem geral do universo, pertence a uma sequência que o nobilita e, sob certo sentido, o perdoa" (BRASIL, 2016, p. 87). Após essa parte, encontra-se a seção A', no quinto capítulo, no qual a narrativa se volta mais para uma descrição da casa de Julius - mas também as impressões psicológicas do protagonista. Nessa seção, há uma expansão das interações entre Julius e outros personagens que habitam a Estância Júpiter, tais como os funcionários da casa e Maria Eduarda, uma jovem sobrinha de um dos empregados mais antigos da Estância, que representa, com sua juventude e alegria, uma fonte de luz em meio a tanta negatividade: "Ela tem suficiente juventude e alegria, uma presença ativa e forte para trazer luz a esta casa" (BRASIL, 2016, p. 193).

A seção $C$ aparece no sétimo capítulo, uma parte repleta de lembranças do passado. O contraste dessa seção é o reencontro de Julius com Klarika Király, uma violoncelista que também estudou em Würzburg, e acompanhou Julius na sua iniciativa de executar o concerto de Dvořák. Essa cena se dá após um instante de "crise" do personagem, ao vasculhar o fato que o levara a voltar ao pampa:

Quer entender todo o acontecido nos últimos tempos, e que resultou na causa imediata de sua vinda para a Fronteira. Quer saber qual fato, qual acontecimento, qual emoção ele não soube entender ou entendeu mal, ou da qual não avaliou as consequências, que resultou nesta sucessão de fatalidades que o deixa indolente e à beira do alcoolismo, em vez de estar estudando seu violoncelo (BRASIL, 2016, p. 252).

Ao reencontrar Klarika, Julius se viu obrigado a cumprir a promessa do passado de tocar o concerto e finalizar essa parte mal resolvida da sua vida. "Hoje ele consegue identificar o momento do seu passo em falso e que fez decidir-se a vir para a estância" (BRASIL, 2016, p. 252). Após o reencontro, promete que na próxima temporada de concertos da sua orquestra iria executar a peça que o atormentava.

Ressalte-se, neste ponto da narrativa, também a ocorrência de um dos fenômenos músico-literários que Steven Paul Scher caracteriza como música verbal. Esta seria uma descrição literária de composições musicais - existentes ou fictícias -, destacando-se, sobretudo, os efeitos da música sobre o ouvinte. Não se trata, claro, de uma imitação literal do som, mas de uma estratégia literária que buscaria levar ao leitor à experiência da musicalidade em uma cena:

[...] a música verbal é um fenômeno literário. Sua textura consiste de palavras organizadas artisticamente que se relacionam com a música apenas na medida em que se esforçam para sugerir a experiência ou os efeitos da música, enquanto permanece necessariamente dentro dos limites do meio da literatura (SCHER, 2004, p. 26, tradução nossa).

A música verbal, não raramente,é encontrada na poesia e prosa brasileiras, como aponta Solange de Oliveira (2003) em seu ensaio sobre a música na literatura brasileira, Introdução à melopoética, descrevendo tal fenômeno nas obras de Drummond e Antônio Callado, por exemplo. No romance em questão, o recurso da descrição musical e seus efeitos sobre um ouvinte é usado em diversos momentos importantes da narrativa. O reencontro entre Julius e KlarikaKirály, em São Paulo,acontece após um concerto em que o protagonista reconhece sua amiga ao ouvi-la tocar. À medida que o solo transcorria, Julius teve o seu passado evocado pelo abismo da memória, vivenciando uma mistura de sentimentos que rompiam a barreira do tempo: "Enquanto transcorria o solo, Julius se viu nas aulas de Bruno Brand, [...], e submerso no amor de Constanza Zabala, percorrendo o terreno indizível do sonho e da imaginação" (BRASIL, 2016, p. 243).

Outra cena importante em que o fenômeno da "música verbal" aparece na narrativa é quando floresce em Julius o desejo de executar o concerto de Dvoř́ák, ainda na Alemanha. Ao chegar mais cedo na sala de aula, Julius ouve seu professor tocar os primeiros compassos do solo do concerto e se encanta pela forma como ele consegue acrescentar não somente sua personalidade à 
execução da peça, mas também uma sentida humanidade, a qual se sabe que Julius almeja alcançar:

Ele largou com cuidado o estojo do violoncelo e ficou quase sem respirar. Era admirável a força que Bruno concentrava em seu magro corpo. Foi esse o momento em que floresceu em Julius o desejo de tocar Dvořák. Poderia, quem sabe, estudar aquele concerto. [...] Era uma pequena luz que surgia (BRASIL, 2016, p. 148).

Finalmente, chega-se à última seção, A" do concerto, na qual Dvořák utiliza material do primeiro e segundo movimentos anexado a uma longa coda, que caminha para um final festivo. Mesmo no clima de festividade, acontece novamente uma referência à canção Lasstmichallein (Deixe-me só), colocada pelo compositor em homenagem melancólica a sua amada Josefina, que no momento da composição já havia falecido. Na narrativa, por contraste, essa seção ocorre nos últimos capítulos, em que são rememoradas passagens da infância de Julius e da sua estadia em Würzburg, bem como ocorre o reencontro com Constanza Zabala.

Tal como o concerto, o romance de Assis Brasil termina num clima festivo, após Julius conseguir executar o concerto, mas ainda assim atravessado poruma reflexão introspectiva, melancólica: "no entanto, para sempre saudoso, solitário e incompleto, tal como os personagens dos romances" (BRASIL, 2016, p. 344), e a suspensão da narrativa, dando ao leitor a sensação de que fomos excluídos de um mundo que só existirá para os personagens.

"Me procure depois do concerto, na Praça. Estarei livre." (BRASIL, 2016, p. 345) é o que diz Constanza em um bilhetedirigido a Julius, após a finalmente exitosa execução do concerto. É a mesma frase enunciada 30 anos antes, na Alemanha, pela mesma personagem, frase que fora ignorada por Julius, e que levou à abrupta interrupção do relacionamento e à volta do músico ao Brasil.

Seja pela relativa abertura ou ambiguidade do final, seja por nossa identificação com as buscas do herói, seja pela força que um amor forte e imperecível exerce sobre nós ou por motivos que não foram aqui citados, sentimos saudade desse universo romanesco tão desejável e magnificamente construído. Ao terminar a leitura, queremos permanecer no romance. Ficamos querendo saber o que acontece depois. E depois? Creio estarem aí reunidos alguns dos porquês da saudade (MUTTER, 2017).

A sintaxe em aberto com a qual é moldado o bilhete que finaliza o romance de Assis Brasil, ritornelo em diferença, harmoniza-se com a virtualidade em expansão contínua da música de Dvořák. Ambos, concerto e romance, harmonizam-se na interpretação compartilhada de ouvintes e leitores.

O brilhante final de uma narrativa construída sob a regência de grande sensibilidade literária e musical corrobora a leitura do romance como rica experiência de modulações entre música e literatura.

\section{Referências}

ASSIS BRASIL, Luiz Antonio de. A margem imóvel do rio. Porto Alegre: L\&PM, 2003.

. Música Perdida. Porto Alegre: L\&PM, 2006.

O pintor de retratos. Porto Alegre: L\&PM, 2006.

O inverno e depois. Porto Alegre: L\&PM, 2016.

A criação literária e música. Letras em Revista, Teresina, v. 06, n. 01, p. 8-15, jan./jun. 2015.

. Literatura e música. In: BRITO, José Domingos de. (Org.). Música e Literatura: depoimentos célebres e bibliografia. São Paulo: Tiro de letra, 2015. p. 11-17.

BACHELARD, Gaston. A poética do espaço. Tradução Antônio da Costa Leal e Lídia do Valle Santos Leal. In: Os Pensadores. São Paulo: Abril, 1974.

BENNETT, Roy. Forma e estrutura na música. Tradução de Luiz Carlos Csëko. Rio de Janeiro: ZAHAR, 2007.

BIAN, Zhuojun. A Pedagogical Analysis of Dvorak's Cello Concerto in B Minor, Op. 104. 2017. 69 f. Tese (Doutorado em Artes Musicais) - The Faculty of Graduate and Postdoctoral studies, The University of British Columbia, Vancouver, 2017.

GRUNER, Ricardo. Luiz Antonio de Assis Brasil, investigador do tempo. 2016. Entrevista. Disponível em: <http://jcrs.uol. com.br/_conteudo/2016/09/cadernos/panorama/521389investigador-do-tempo.html>. Acesso em: 16 set. 2017.

KRISTEVA, Julia. Estrangeiros para nós mesmos. Tradução Maria Carlota C. Gomes. Rio de Janeiro: Rocco, 1994.

MOSER, Walter. As relações entre as artes: por uma arqueologia da intermidialidade. Tradução da revista Aletria. Belo Horizonte: UFMG, 2006.

MOTA, Ricardo Paiva Rodrigues Bártolo. Concerto para violoncelo e orquestra em Si menor, Op. 104, de Antonín Dvoŕák: a obra enquanto objecto para a elaboração de um documento pedagógico. 2015. 223 f. Dissertação (Mestrado em Música) - Curso de Pós-Graduação em Ensino de Música, Faculdade de Ciências Humanas e Sociais da Universidade Lusíada de Lisboa, Lisboa. 2015.

MUTTER, Débora. O inverno e depois. E depois? 2017. Disponível em: <http://homoliteratus.com/o-inverno-e-depoise-depois/>. Acesso em: 06 maio 2017.

OLIVEIRA, Solange Ribeiro. Literatura e música: modulações pós-coloniais. São Paulo: Perspectiva, 2002.

et al. Literatura e música. São Paulo: Editora Senac São Paulo/Instituto Itaú Cultural, 2003.

PELINSER, A. T.; CURY, M. Z. F. Narrativas ao Sul: viagem e música em quatro romances de Assis Brasil. Estudos de Literatura Brasileira Contemporânea, v. 44, p. 365-387, 2014. 
POMBO, Fátima. Concerto para violoncelo e orquestra em Si menor, op. 104. 2007. Disponível em: <http://www. casadamusica.com/artistas-e-obras/obras/c/concerto-paravioloncelo-e-orquestra-em-si-menor-op 104-antonin-dvo $\% \mathrm{C} 5 \%$ 99ak/\#tab=0>. Acesso em: 26 ago. 2017.

SANTIAGO, Silviano. A estrutura musical no romance: o caso Érico Veríssimo. In: SANTIAGO, Silviano. Nas malhas da letra: ensaios. Rio de Janeiro: Rocco, 2002. p. 164-186.

SEROTSKY, Paul. Dvorák (1841-1904) - 'Cello Concerto. 2009. Disponível em: <http://www.musicweb-international. com/Programme_Notes/dvorak_celloconc.htm>. Acesso em: 13 out. 2017.

SUPKA, Ondrej. Concerto for cello and orchestra.2013. Traduzido para o inglês por Karolina Hughes. Disponível em: <http://www.antonin-dvorak.cz/en/concerto-for-cello2>. Acesso em: 07 out. 2017.

SCHER, Steven Paul. Notes Toward a Theory of Verbal Music. In: BERNHART, Walter; WOLF, Werner (Org.). Word and music studies 5. Essays on literature and music (1967-2004) by Steven Paul Scher. Amsterdam; New York, NY: Rodopi, 2004.

WOLF, Werner. Musicalized fiction and intermidiality: theoretical aspects of word and music studies. In: BERNHART, Walter; SCHER, Steven Paul; WOLF, Werner (Org.). Word and musicstudies:Defining the Field. Amsterdam; Atlanta: Rodopi, 1999. p. 37-58.

\section{Autores:}

MARIA ZILDA FERREIRA CURY (correspondente)

Professora da Faculdade de Letras da UFMG. Coordenadora do Programa de Pós-Graduação em Estudos Literários da UFMG. mariazildacury@gmail

GUILHERME Augusto LOPES DE SOUZA

Violista da Orquestra do Tribunal de Justiça de Minas Gerais. Graduando em Letras - UFMG/CNPq.

guilhermealopes@live.com

Recebido: 10/06/2018

Aprovado: 10/06/2018 